\title{
The hemostatic effect of calcium alginate in experimental splenic injury model
}

\section{Deneysel dalak yaralanma modelinde kalsiyum alginatın hemostatik etkinliği}

\author{
Ali Kemal TAŞKIN, ${ }^{1}$ Mehmet YAŞAR, ${ }^{1}$ İsmet ÖZAYDIN, ${ }^{1}$ Bülent KAYA, ${ }^{2}$ Orhan BAT, ${ }^{2}$ \\ Seyit ANKARALI, ${ }^{3}$ Ümran YILDIRIM, ${ }^{4}$ Metin AYDIN ${ }^{1}$
}

\section{BACKGROUND}

We evaluated the effect of calcium alginate as a hemostatic agent in a splenic injury model.

\section{METHODS}

Experimental rats (Wistar albino) were divided into four groups. Group I: Laparotomy was not performed. Group II: After laparotomy, the abdomen was closed without any splenic injury. Group III: After laparotomy, splenic injury about $0.5 \mathrm{~cm}$ in depth and $0.3 \mathrm{~cm}$ in length was created by standard Rochester pean forceps. Physiological serum treated gauze dressing, about $2 \times 2 \mathrm{~cm}$ in size, was applied to the injured splenic tissue for 3 minutes. Group IV: After laparotomy, standard splenic injury about $0.5 \mathrm{~cm}$ in length and $0.3 \mathrm{~cm}$ in depth was created. Calcium alginate wound dressing, $1 \times 1 \mathrm{~cm}$ in size, was applied to the splenic wound. In all groups, blood samples for bleeding time and hemogram were taken. Peroperative blood loss, pre- and post-operative hemoglobin and hematocrit values were calculated.

\section{RESULTS}

Comparing hematocrit values and peroperative bleeding in Groups III and IV, Group IV had a lower decline in hematocrit values and lower peroperative bleeding.

\section{CONCLUSION}

Calcium alginate has hemostatic capacity. It may be used in splenic injuries, especially for Grades I and II.

Key Words: Calcium alginate; hemostasis; splenic injury.

\section{AMAÇ}

Kalsiyum alginatın deneysel dalak yaralanma modelinde etkinliği araştırıldı.

\section{GEREÇ VE YÖNTEM}

Deney hayvanları (Wistar albino sıçanlar) dört gruba ayrıldı. Grup I: Laparotomi uygulanmadı. Sadece kan örneklemesi yapılarak kanama zamanı ve hemogram incelemesi çalışıldı. Grup II: Laparotomi yapıldı. Herhangi bir dalak yaralanması oluşturmaksızın karın kapatıldı. Grup III: Laparotomi yapıldıktan sonra $0,5 \mathrm{~cm}$ derinlik ve $0,3 \mathrm{~cm}$ uzunluğunda dalak yaralanması oluşturuldu. Yaklaşık 2x2 $\mathrm{cm}$ ebadında serum fizyolojikli gazlar dalaktaki yaralanma bölgesine uygulandı. Grup IV: Laparatomi sonrası standart $0,5 \mathrm{~cm}$ derinlik ve $0,3 \mathrm{~cm}$ uzunluğundaki dalak yaralanması bu grupta da uygulandı. $1 \times 1 \mathrm{~cm}$ ebadındaki kalsiyum alginat yara örtüsü yaralanma bölgesine kondu. Ameliyat sırasında kan kaybı, ameliyat öncesi ve sonrası hemoglobin ve hemotokrit değerleri ölçüldü.

\section{BULGULAR}

Grup III ve Grup IV hematokrit değerleri ve ameliyat s1rasında kanama miktarı açısından karşılaştırıldığında Grup IV'deki düşüş miktarı daha azdı.

\section{SONUC}

Kalsiyum alginatın hemostatik kapasitesi vardır. Grade I ve grade II dalak yaralanmalarında kullanılabilir.

Anahtar Sözcükler: Kalsiyum alginat; hemostaz; dalak yaralanması.
Alginate dressings are hydrophilic products which are formed by alginic acids (mannuronic and guluronic) extracted from seaweed species. ${ }^{[1]}$ They are highly absorbent, gel-forming materials with haemostatic capacity. Alginate dressings were first presented as wound care and haemostatic products. Alginate dressings have been used to treat different wound types, as they absorb any fluid collection inside a wound and
Departments of ${ }^{1}$ General Surgery, ${ }^{3}$ Physiology, ${ }^{4}$ Pathology, Duzce University Faculty of Medicine, Duzce;

${ }^{2}$ Department of General Surgery, Fatih Sultan Mehmet Training and Research Hospital, Istanbul, Turkey.
Düzce Üniversitesi Tıp Fakültesi ${ }^{1}$ Genel Cerrahi Anabilim Dalı, ${ }^{3}$ Fizyoloji Anabilim Dalı, ${ }^{4}$ Patoloji Anabilim Dalı, Düzce; ${ }^{2}$ Fatih Sultan Mehmet Eğitim ve Araștırma Hastanesi Genel Cerrahi Kliniği, İstanbul.

Correspondence (Illetişim): Bülent Kaya, M.D. Fatih Sultan Mehmet Eğitim ve Araştırma Hastanesi, Genel Cerrahi Kliniği, İstanbul, Turkey. Tel: +90 - 216 - 5783000 e-mail (e-posta): drbkaya@yahoo.com 
favour debridement. Thus, they promote wound healing and epidermal regeneration.

When alginate is combined with calcium or sodium it gains hemostatic properties. Calcium alginate dressings form a gel when in contact with body fluids. In dentistry, alginate products are used widely to control bleeding in tooth sockets. ${ }^{[2]}$ The availability of calcium ions at the injury site helps to support the normal clotting process, and this has been shown to significantly reduce clotting times, in some cases up to $54 \%$ compared to controls. ${ }^{[2]}$

Calcium alginate dressing is tailored as a textile product. It is designed for cavity wounds such as pilonidal sinus cavity or tooth cavity after extraction process. There are also flat-non-woven pad models for application to open wounds. In this experimantal study, we evaluated the effect of calcium alginate as a hemostatic agent in a splenic injury model. Intraabdominal adhesion formation with calcium alginate usage was also studied.

\section{MATERIALS AND METHODS}

This study was conducted in Duzce University Medical Faculty Research Center.The experimental protocol was approved by the animal studies and ethical committee of Abant Izzet Baysal University
Medical Faculty. Thirty-two male Wistar albino rats weighting 250-300 g (mean age: 6 months) were used. The rats were fed with standard rat chow diet. Experimental rats were divided into four groups: Group I (Control group): Laparotomy was not performed; Group II (Sham group): After laparotomy, the abdomen was closed without any splenic injury; Group III (Splenic injury treated by gauze dressing with serum physiologic): After laparotomy, splenic injury about $0.5 \mathrm{~cm}$ in depth and $0.3 \mathrm{~cm}$ in length was created by standard Rochester pean forceps. Physiological serum treated gauze dressing, about $2 \times 2 \mathrm{~cm}$ in size, was applied to the injured splenic tissue for 3 minutes (Fig. 1a). Gauze was taken out after 3 minutes; Group IV (Splenic injury treated with calcium alginate): after laparotomy, standard splenic injury about $0.5 \mathrm{~cm}$ in length and $0.3 \mathrm{~cm}$ in depth was created. Calsium alginate wound dressing $1 \mathrm{x} 1 \mathrm{~cm}$ in size was applied to the splenic wound (Fig. 1b).

During the surgical procedure, the rats were under general anaesthesia using an intramuscular injection of $20 \mathrm{mg} / \mathrm{kg}$ ketamin hydrocholoride (Ketalar ${ }^{\circledR}$, Parke Davis, Levent-İstanbul, Turkey) and $2 \mathrm{mg} / \mathrm{kg}$ xylasin (Rhompun $^{\circledR}$, Bayer Türk Kimya, Şişli-İstanbul, Turkey). After cleaning the abdominal region of rats with poidon iot solution, a $3 \mathrm{~cm}$ median laparotomy was performed in all groups except Group I (controls). Be-
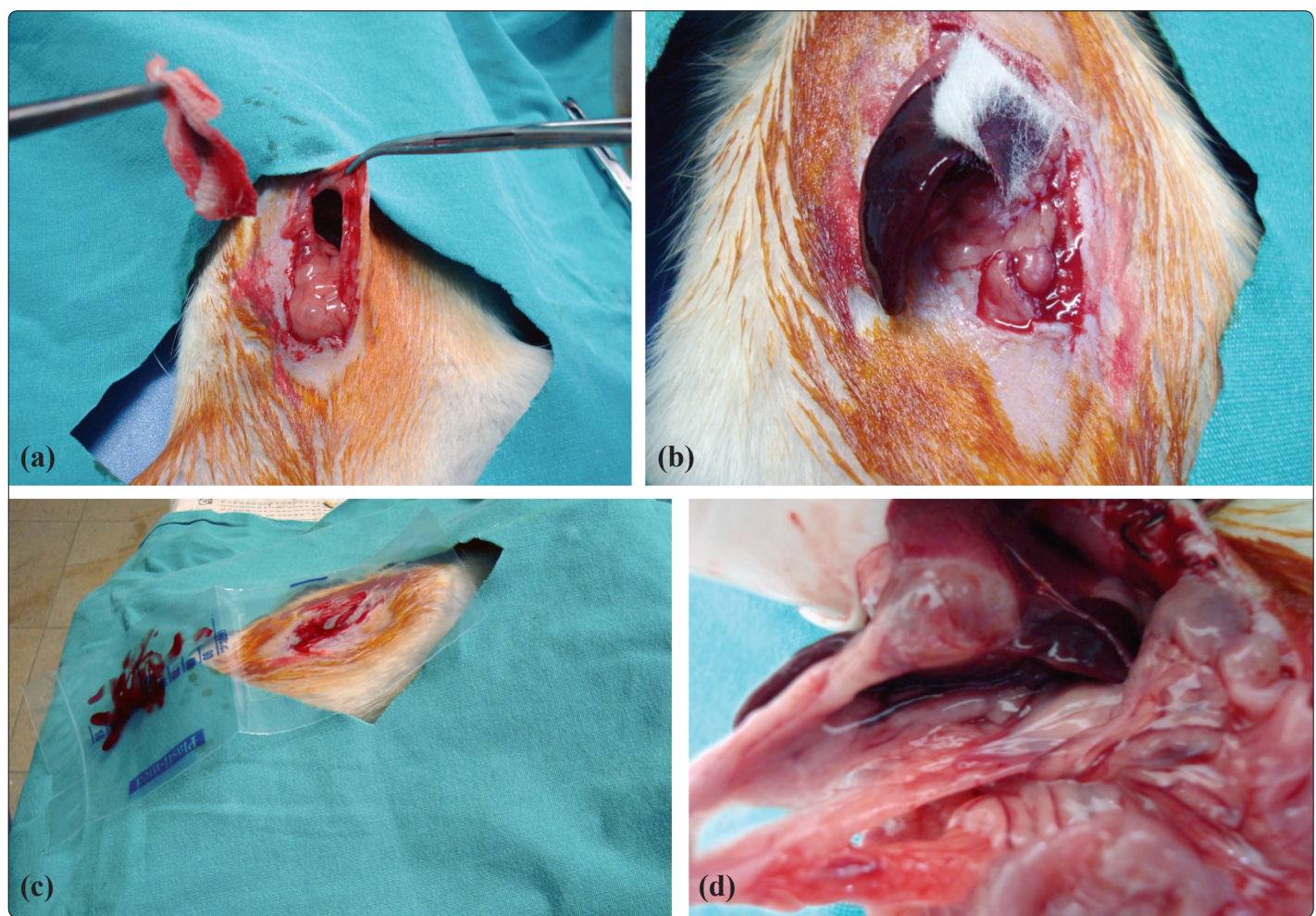

Fig. 1. (a) Polyester bag was placed for collecting accumulated blood after splenic injury. (b) Gauze dressing with $0.9 \% \mathrm{NaCl}$ applied to splenic injury. (c) Calcium alginate dressing (Sorbalgon) $1 \times 1 \mathrm{~cm}$ applied to splenic injury. (d) Stage 3 adhesion in rats treated with Ca-alginate dressing.

(Color figures can be viewed in the online issue, which is available at www.tjtes.org). 
Table 1. Comparison of postoperative laboratory values in four groups

\begin{tabular}{|c|c|c|c|c|c|c|c|c|c|}
\hline \multirow[b]{2}{*}{ Postoperative } & \multicolumn{2}{|c|}{$\begin{array}{l}\text { Sham group } \\
\qquad(\mathrm{n}=8)\end{array}$} & \multicolumn{2}{|c|}{$\begin{array}{c}\text { Gauze dressing with } \\
0.9 \% \mathrm{NaCl}(\mathrm{n}=8)\end{array}$} & \multicolumn{2}{|c|}{$\begin{array}{l}\text { Ca-alginate dressing } \\
\qquad(\mathrm{n}=8)\end{array}$} & \multicolumn{2}{|c|}{$\begin{array}{l}\text { Control group } \\
(\mathrm{n}=8)\end{array}$} & \multirow[t]{2}{*}{$p$} \\
\hline & Mean \pm SD & Min.-Max. & Mean \pm SD & Min.-Max. & Mean \pm SD & Min.-Max. & Mean \pm SD & Min.-Max. & \\
\hline $\mathrm{Wbc}$ & $8.22 \pm 4.68$ & $3-14$ & $7.47 \pm 3.54$ & $3.3-13.50$ & $9.41 \pm 4.26$ & $4.43-15.20$ & $8.59 \pm .418$ & $4.07-13.60$ & 0.87 \\
\hline $\mathrm{Rbc}$ & $8.27 \pm 1.31$ & $5.9-9.7$ & $8.41 \pm .35$ & 8-8.8 & $8.16 \pm .777$ & $6.70-8.78$ & $8.51 \pm .409$ & $7.85-8.96$ & 0.79 \\
\hline $\mathrm{Hb}$ & $13.93 \pm 1.81$ & $10.6-15.6$ & $13.07 \pm 1.18$ & $10.9-14.4$ & $14.74 \pm 1.08$ & $13.5-16.2$ & $14.33 \pm .663$ & $13.20-15.10$ & 0.05 \\
\hline Het & $64.53 \pm 2.72$ & $60.3-67.9$ & $55.05 \pm 2.98$ & $50.2-58.7$ & $61.38 \pm 3.37$ & $56.7-65.6$ & $65.43 \pm 2.95$ & $60.3-67.9$ & 0.0005 \\
\hline BT & $11.0 \pm .707$ & 10-12 & $11.00 \pm .755$ & 10-12 & $10.87 \pm .51$ & $10.5-12$ & $11.18 \pm .703$ & 10-12 & 0.79 \\
\hline Plt & $937.5 \pm 136.99$ & $675-1050$ & $918.28 \pm 246.02$ & $600-1240$ & $747.0 \pm 199.696$ & $420-1080$ & $789.37 \pm 139.704$ & $560-950$ & 0.16 \\
\hline Perop. bleeding & $.35 \pm .104$ & $.20-.50$ & $1.80 \pm .130$ & $1.6-2$ & $.95 \pm .169$ & $.70-1.2$ & - & - & 0.0004 \\
\hline
\end{tabular}

BT: Bleeding time.

fore splenic injury, a funnel shape polyster bag was placed under the spleen (Fig. 1c). Approximately 10 minutes after laparatomy and splenic injury, accumulated blood was taken from polyester bag by injector and peroperative blood loss was calculated. The polyester bag was removed from the abdominal cavity and the abdomen was closed with $3 / 0$ silk sutures. Re-laparatomy was performed seven days after the first operation for histopathological examination. Adhesion scoring was performed with adhesion scoring system. After adhesion evaluation, splenectomy was performed. Inflammatory cell amount, vascularization, and fibroblast number were evaluated and scored as $(-),(+),(++),(+++)$.

\section{RESULTS}

Preoperative mean values for WBC, RBC, hemoglobin, hematocrit, and thrombocyte count were measured. There were no statistically significant differences between the 4 groups ( $p>0.05$ ).

Postoperative values including WBC, RBC, hemoglobin, hematocrit and amount of bleeding are shown in Table 1. When comparing postoperative hemoglobin, hematocrit values and amount of bleeding, there were statistically significant differences between groups $(\mathrm{p}<0.05)$. Postoperative hematocrit and hemoglobin values were significantly lower in gauze dressing with $0.9 \% \mathrm{NaCl}$ group (Table 1 ). When comparing the decline in hematorit values and peroperative bleeding amount between Group III and Group IV, Group IV had a lower decline in hematocrit values and less peroperative bleeding (Tables 2 and 3).

Pathological results and adhesion scores are shown in Table 4. There were statistically significant differences between Group III and Group IV in inflammation, vascularization and fibrosis $(\mathrm{p}<0.05)$. The highest adhesion score was detected in Group IV (Fig. 1d).

\section{DISCUSSION}

Several hemostatic agents have been used in the treatment of solid organ hemorrhages. ${ }^{[3-5]}$ They work by different mechanisms. Some stimulate fibrin formation or inhibit fibrinolysis. Some hemostatics are a preparation of a procoagulant agent combined with a transporter molecule such as collagen matrix. All have effects on hemostasis mechanisms.

Alginate is formed by Alpha-L-Glucuronic acid and Beta-D-Mannuroic acid monomers. When two molecules of calcium combine with alginate, calcium alginate is formed. Calcium alginate has been used as

Table 2. Decline in hematocrit values in Gauze dressing and Ca-alginate dressing

\begin{tabular}{lccc}
\hline & $\begin{array}{c}\text { Gauze dressing with } 0.9 \% \mathrm{NaCl} \\
\text { Mean } \pm \text { SD }\end{array}$ & $\begin{array}{c}\text { Ca-alginate dressing } \\
\text { Mean } \pm \text { SD }\end{array}$ & $p$ \\
\hline $\begin{array}{l}\text { Differance in Htc values } \\
\text { (preop-postop) }\end{array}$ & $9.3 \pm 2.22$ & $3.81 \pm 0.67$ & $\mathbf{0 . 0 0 1}$ \\
\hline
\end{tabular}

Table 3. Comparison of bleeding amount in Gauze dressing and Ca-alginate dressing

\begin{tabular}{lccc}
\hline & $\begin{array}{c}\text { Gauze dressing with } 0.9 \% \mathrm{NaCl} \\
\text { Mean } \pm \text { SD }\end{array}$ & $\begin{array}{c}\text { Ca-alginate dressing } \\
\text { Mean } \pm \text { SD }\end{array}$ & $p$ \\
\hline $\begin{array}{l}\text { Peroperative } \\
\text { Bleeding }(\mathrm{ml})\end{array}$ & $1.80 \pm 1.30$ & $0.95 \pm 0.169$ & $\mathbf{0 . 0 0 1}$ \\
\hline
\end{tabular}


Table 4. Patological results in four groups including adhesion scores

\begin{tabular}{|c|c|c|c|c|c|c|c|c|c|c|}
\hline \multirow{2}{*}{\multicolumn{2}{|c|}{ Pathological findings }} & \multicolumn{2}{|c|}{ Sham group } & \multicolumn{2}{|c|}{$\begin{array}{c}\text { Gauze dressing } \\
\text { with } 0.9 \% \mathrm{NaCl}\end{array}$} & \multicolumn{2}{|c|}{$\begin{array}{l}\text { Ca-alginate } \\
\text { dressing }\end{array}$} & \multicolumn{2}{|c|}{ Control group } & \multirow[t]{2}{*}{$p$} \\
\hline & & $\mathrm{n}$ & $\%$ & $\mathrm{n}$ & $\%$ & $\mathrm{n}$ & $\%$ & $\mathrm{n}$ & $\%$ & \\
\hline \multirow[t]{3}{*}{ Inflammation } & 0 & 8 & 100 & 0 & 0 & 0 & 0 & 8 & 100 & \multirow[t]{3}{*}{0.0001} \\
\hline & 1 & 0 & 0 & 8 & 100 & 4 & 50 & 0 & 0 & \\
\hline & 2 & 0 & 0 & 0 & 0 & 4 & 50 & 0 & 0 & \\
\hline \multirow[t]{3}{*}{ Vascularization } & 0 & 8 & 100 & 1 & 12.5 & 0 & 0 & 8 & 100 & \multirow[t]{3}{*}{0.0001} \\
\hline & 1 & 0 & 0 & 7 & 87.5 & 4 & 50 & 0 & 0 & \\
\hline & 2 & 0 & 0 & 0 & 0 & 4 & 50 & 0 & 0 & \\
\hline \multirow[t]{4}{*}{ Fibrosis } & 0 & 8 & 100 & 0 & 0 & 0 & 0 & 8 & 100 & \multirow[t]{4}{*}{0.0001} \\
\hline & 1 & 0 & 0 & 5 & 62.5 & 0 & 0 & 0 & 0 & \\
\hline & 2 & 0 & 0 & 3 & 37.5 & 6 & 75 & 0 & 0 & \\
\hline & 3 & 0 & 0 & 0 & 0 & 2 & 25 & 0 & 0 & \\
\hline Necrosis & 0 & 0 & 100 & 0 & 100 & 0 & 100 & 0 & 100 & 1.000 \\
\hline \multirow[t]{5}{*}{ Adhesion } & 0 & 4 & 50 & 1 & 12.5 & 0 & 0 & 8 & 100 & \multirow[t]{5}{*}{0.003} \\
\hline & 1 & 4 & 50 & 6 & 75 & 5 & 62.5 & 0 & 0 & \\
\hline & 2 & 0 & 0 & 1 & 12.5 & 2 & 25 & 0 & 0 & \\
\hline & 3 & 0 & 0 & 0 & 0 & 1 & 12.5 & 0 & 0 & \\
\hline & 4 & 0 & 0 & 0 & 0 & 0 & 0 & 0 & 0 & \\
\hline
\end{tabular}

a local hemostatic agent and wound dressing in recent years. ${ }^{[6,7]}$ When calcium alginate contacts tissue, calcium and sodium ions are exchanged. Calcium has an important role in hemostasis. It is known as factor IV in the hemostasis cascade. It causes secretion of hemostatic mediators from thrombocytes by the help of calcium ions. ${ }^{[8-11]}$ It activates thrombocytes, Factor VII-IX and $\mathrm{X}$ in hemostasis.

In this experimental study, a spleen laceration model was established and the hemostatic effect of calcium alginate was evaluated. It was demonstrated that calcium alginate was able to decrease the intraoperative bleeding after splenic injury. It was also associated with a lesser decrease in hemoglobin and hemotocrit levels in the postoperative period when compared to $0.9 \% \mathrm{NaCl}$ treated gauze dressing. Henderson et al. ${ }^{[12]}$ used calcium alginate as a hemostatic agent in children after tooth extraction. They compared the cotton swab with alginate swab for hemostasis. They concluded that calcium alginate swabs did not have any clinical or statistical advantage over traditional cotton swabs. Ingram et al. ${ }^{[13]}$ used calcium alginate (Sorbsan) and standard gauze packing following haemorrhoidectomy. Although calcium alginate dressing effectively decreased the postoperative pain compared to standard gauze packing, there were no differences in postoperative hemorrhage. Calcium alginate was also used as a hemostatic swab in hip fracture surgery, where alginate swabs significantly decreased intra-operative blood loss and post-operative suction drainage loss. ${ }^{[14]}$ Mlekusch et al. ${ }^{[15]}$ used calcium alginate pads for access site management after peripheral percutaneous transluminal procedures. Calcium alginate pad were compared with conventional comprasion. They concluded that, although calcium alginate pads reduced the time to hemostasis, the risk of access site complications was not significantly different.

Although it was not main objective of this study, development of intraabdominal adhesions after calcium alginate usage was also evaluated. El-Kamel et al. ${ }^{[16]}$ used sodium alginate in formulation of vaginal tablets as a bioadhesive molecule. Calcium-alginate was placed on to the lacerated spleen. It did not dissolve, and adhesions around the lacerated spleen were detected. When compared to $0.9 \% \mathrm{NaCl}$ gauze and sham groups, inflammation, vascularization and fibrosis were statistically higher in calcium alginate group $(p<0.05)$. The adhesion score was also higher in calcium alginate group. These results were associated with higher incidence of adhesion formation in calcium alginate group. Higher inflammation and vascularization in calcium alginate group may be associated with rapid wound healing.

In conclucion, calcium alginate has hemostatic capacity. It may be used in splenic injuries specially for Grade I and II, but it may be associated with intraabdominal adhesion formation.

Conflict-of-interest issues regarding the authorship or article: None declared. 


\section{REFERENCES}

1. Timmons J. Alginates and hydrofibre dressings. Prof Nurse 1999;14:496-9, 501, 503.

2. Kaneda K, Kuroda S, Goto N, Sato D, Ohya K, Kasugai S. Is sodium alginate an alternative haemostatic material in the tooth extraction socket? J Oral Tissue Engin 2008;5:127-33.

3. Bilgili H, Kosar A, Kurt M, Onal IK, Goker H, Captug O, et al. Hemostatic efficacy of Ankaferd Blood Stopper in a swine bleeding model. Med Princ Pract 2009;18:165-9.

4. Schwaitzberg SD, Chan MW, Cole DJ, Read M, Nichols T, Bellinger D, et al. Comparison of poly-N-acetyl glucosamine with commercially available topical hemostats for achieving hemostasis in coagulopathic models of splenic hemorrhage. J Trauma 2004;57:S29-32.

5. Chan MW, Schwaitzberg SD, Demcheva M, Vournakis J, Finkielsztein S, Connolly RJ. Comparison of poly-N-acetyl glucosamine (P-GlcNAc) with absorbable collagen (Actifoam), and fibrin sealant (Bolheal) for achieving hemostasis in a swine model of splenic hemorrhage. J Trauma 2000;48:454-8.

6. Qin Y. Absorption characteristics of alginate wound dressings. J Appl Polym Sci 2004;91:953-7.

7. Gilchrist T, Martin AM. Wound treatment with Sorbsan-an alginate fibre dressing. Biomaterials 1983;4:317-20.

8. Biggs G, Hafron J, Feliciano J, Hoenig DM. Treatment of splenic injury during laparoscopic nephrectomy with BioGlue, a surgical adhesive. Urology 2005;66:882.

9. Berrevoet F, de Hemptinne B. Clinical application of topi- cal sealants in liver surgery: does it work? Acta Chir Belg 2007; 107:504-7.

10. Demirel AH, Basar OT, Ongoren AU, Bayram E, Kisakurek M. Effects of primary suture and fibrin sealant on hemostasis and liver regeneration in an experimental liver injury. World J Gastroenterol 2008;14:81-4.

11. Schwartz M, Madariaga J, Hirose R, Shaver TR, Sher L, Chari R, et al. Comparison of a new fibrin sealant with standard topical hemostatic agents. Arch Surg 2004;139:1148-54.

12. Henderson NJ, Crawford PJ, Reeves BC. A randomised trial of calcium alginate swabs to control blood loss in 3-5-yearold children. Br Dent J 1998;184:187-90.

13. Ingram M, Wright TA, Ingoldby CJ. A prospective randomized study of calcium alginate (Sorbsan) versus standard gauze packing following haemorrhoidectomy. J R Coll Surg Edinb 1998;43:308-9.

14. Davies MS, Flannery MC, McCollum CN. Calcium alginate as haemostatic swabs in hip fracture surgery. J R Coll Surg Edinb 1997;42:31-2.

15. Mlekusch W, Dick P, Haumer M, Sabeti S, Minar E, Schillinger M. Arterial puncture site management after percutaneous transluminal procedures using a hemostatic wound dressing (Clo-Sur P.A.D.) versus conventional manual compression: a randomized controlled trial. J Endovasc Ther 2006;13:23-31.

16. El-Kamel A, Sokar M, Naggar V, Al Gamal S. Chitosan and sodium alginate-based bioadhesive vaginal tablets. AAPS PharmSci 2002;4:E44. 